\title{
Chemical evaluation and effect of bagging new peach varieties introduced in southern Minas Gerais - Brazil
}

Annete de Jesus Boari LIMA ${ }^{1 *}$, Ângelo Alberico ALVARENGA ${ }^{1}$, Marcelo Ribeiro MALTA ${ }^{1}$, Deyse GEBERT ${ }^{2}$, Elisa Boari de LIMA ${ }^{3}$

\begin{abstract}
Brazilian peach production is insufficient for domestic supply. Aiming to increase production in the state of Minas Gerais, 16 new peach tree varieties were introduced in the Serra da Mantiqueira region and their fruit were analyzed for sugar, total phenol and total carotenoid contents by colorimetric methods, and for organic acid content by high-performance liquid chromatography. In addition, we examined the effect of fruit bagging on the levels of such constituents. To do so, the fruit of half the trees of each variety were bagged. The levels of sugars, phenols, carotenoids and organic acids are genotypic characteristics and significantly differed among varieties. Despite being a good form of fruit protection, providing better aspect and reducing the need for pesticides, bagging leads to lower contents of components such as sugars, phenols and organic acids in most varieties. However, it cannot be stated that this practice interferes with sensory characteristics. Knowledge of the chemical constituents of these new varieties allows determining those ideal for fresh consumption (e.g., "Maciel", "Diamante", "T. Beauty", "Ouromel 2 " and "C.1056", among others) and those more suitable for industrial processing (e.g., "A. Gold”, "C.1122” and "C.1050"), as well as those which serve both purposes.
\end{abstract}

Keywords: peach; chemical constituents; bagging.

\section{Introduction}

Brazil is among the fifteen largest Prunus persica (L.) Batsch peach producers. However, current production is insufficient for domestic supply, both for industrial processing and for fresh consumption (EMBRAPA, 2005). The state of Minas Gerais is Brazil's third largest producer (INSTITUTO..., 2010), cultivating the least cold demanding varieties and with potential to increase production. Thus, there is a search for new adaptable cultivars that produce well good quality fruit.

Peaches are much appreciated fruits of great commercial importance. Flavor and aroma result from the balance of sugars, organic acids, phenolic compounds, carotenoids and volatile compounds (TORALLES et al., 2008).

Fruit consumption has increased due to public awareness that they are sources of essential elements such as sugars, organic acids, minerals, vitamins and bioactive compounds, thus being potential functional foods. Such compounds include phenols, carotenoids and Vitamins $\mathrm{C}$ and $\mathrm{E}$, which present antioxidant activity (CANTÍN; MORENO; GOGORCENA, 2009). According to Lima et al. (2011), the antioxidant activity of phenolic compounds in living organisms depends on the plant species, geographical origin and harvest time, and has the ability to inhibit and reduce damage in the cells caused by free radicals derived from cellular metabolism, which may lead to diseases such as cancer, neurodegenerative disorders, cardiovascular diseases and other chronic conditions (WANG et al., 1993).
Carotenoid antioxidant activity is related to their role in preventing diseases associated with oxidative stress such as cancer, cataracts, atherosclerosis and delay of the aging process (RIBEIRO; SERAVALLI, 2004).

Peaches are fruit whose cultivars change often due to breeding efforts that search for varieties adaptable to places where climate reaches around 100 hours of hibernal cold at $7{ }^{\circ} \mathrm{C}$, obtaining good fruit production for both fresh consumption and industrial processing. New cultivar properties should include various factors, such as reduced tree growth, resistance to diseases and pests, appropriate maturation time, and production of good quality fruit: excellent flavor, high sugar content and a balanced ratio between sugars and acids (COLARIC; HUDINA, 2004).

Despite being labor-intensive and difficult to practice in large orchards, fruit bagging is used to control pests such as fruit flies (Anastrepha fraterculus, A. obliqua and Ceratitis capitata), especially in orchards that aim to produce fruit with better aspect while using less pesticides. Bagging may also improve fruit color and aspect, as well as reduce and prevent diseases (COELHO et al., 2008). There are several studies on the best material for bagging, but little is known about the effects of bagging on fruit chemical constituents.

Given the fruit of peach cultivars and advanced selections from the 2010 harvest, this work aimed to analyze the levels of sugars, total phenols, total carotenoids and organic acids.

\footnotetext{
Received $1 / 8 / 2012$

Accepted 26/6/2013 (005798)

${ }^{1}$ Unidade Regional do Sul de Minas, Empresa de Pesquisa Agropecuária de Minas Gerais - EPAMIG, Campus da Universidade Federal de Lavras - UFLA, CP 176, CEP 37200-000, Lavras,MG, Brasil, e-mail:anneteboari@gmail.com

2 Departamento de Ciências Exatas, Universidade Federal de Lavras - UFLA, Lavras, MG, Brasil

${ }^{3}$ Departamento de Ciência da Computação, Universidade Federal de Minas Gerais - UFMG, Campus Pampulha, Belo Horizonte, MG, Brasil

${ }^{*}$ Corresponding author
} 
Additionally, we aim to determine whether fruit bagging interferes with such levels under the climate conditions of Serra da Mantiqueira.

\section{Materials and methods}

\subsection{Samples}

Aiming to increase peach production in the state of Minas Gerais, 16 new peach tree varieties have been tested in the Serra da Mantiqueira area in search for those that best adapt to the region while meeting consumer preferences as well as market and industry needs. Most of the varieties originated from Embrapa Clima Temperado in Pelotas/RS and Instituto Agronômico de Campinas (IAC) breeding programs.

The experiment was conducted at the Epamig Experimental Farm in Maria da Fé, southern Minas Gerais (latitude $22^{\circ} 18^{\prime}$ $28^{\prime \prime} \mathrm{S}$ and longitude $45^{\circ} 22^{\prime} 30^{\prime \prime} \mathrm{W}$ ). The analyzed varieties are “Cascata 663” (C.663), “Cascata 1015” (C.1015), "Conserva 693” (C.693), “Conserva 845” (C.845), “Conserva 1050” (C.1050), “Conserva 1122” (C.1122), "Conserva 843” (C.843), "BRS Libra”, "Diamante", "Fla 8813", "Ouromel 2", "Sensação", “Tropic Beauty" (T. Beauty), "Azetec Gold” (A. Gold), "Cascata 1056” (C.1056), and "Maciel". All varieties have early or medium maturation, with harvests between October and December, when the fruit has the best prices. Varieties "Cascata" and "Conserva" are currently being tested by producers and institutions, thus have not yet been released for planting. Thus, there are few data on their performance.

Each plot (i.e., variety) was composed of 8 plants arranged in a $6 \times 4 \mathrm{~m}$ space. Half the plants had their fruit bagged after thinning, while for the other half, which will be called "non-bagged", the fruit fly was controlled by monitoring and application of insecticides Decis (Fention) and Lebaycid (Deltamethrin). White polyethylene plastic bags were used, with perforated bottoms surrounding the fruit and handles attached to the branch.

Ripe fruit were harvested in the mornings from October $8^{\text {th }}$ to November $25^{\text {th }}, 2010$, based on yellow coloration and ease of detachment from the stem. We selected those without defects and with uniform size, washed and sanitized them with sodium hypochlorite $\left(200 \mathrm{mg} \mathrm{L}^{-1}\right)$ by ten-minute immersions, and separated in three ten-fruit repetitions. Pulp and skin were crushed in a blender, packaged, labeled and stored in a freezer until analysis.

\subsection{Chemical analysis}

\section{Colorimetric determination of sugars}

Levels of total sugars, both reducing and non-reducing, were evaluated. Sugars were extracted by the Lane-Eynon method (ASSOCIATION..., 1990) and determined by the Somogyi method adapted by Nelson (1944).

The sucrose (non-reducing sugar) content was obtained by the difference between levels of total and reducing sugars before and after acid hydrolysis, since multiplying the difference between these values by 0.95 (the inverted sugar to sucrose conversion factor) corresponds to the amount of sucrose in solution. Analyses were performed in triplicate.

\section{Analysis of total phenols}

Phenols were measured in a 50\% methanol extract according to the methodology described by Folin-Denis (ASSOCIATION..., 1990), in which the reactant reduction by phenolic compounds in the samples at an intense blue is measured spectrophotometrically at $760 \mathrm{~nm}$. Concentrations were calculated using an analytical curve that considers tannic acid as standard, and results are expressed in mg of tannic acid per $100 \mathrm{~g}$ of the whole-fruit puree.

\section{Analysis of total carotenoids}

Total carotenoid levels were determined spectrophotometrically according to the method of Higby (1962), which uses isopropyl alcohol and hexane to extract carotenoid compounds with two consecutive washings with water, which is discarded by filtering after rest. To the hexane extract, we added $5 \mathrm{~mL}$ of acetone in a volumetric flask, completing $50 \mathrm{~mL}$ with hexane, and performed the reading at $450 \mathrm{~nm}$ in a spectrophotomer. Results are expressed in $\mathrm{mg}^{100 \mathrm{~g}^{-1}}$.

\section{Extraction and determination of organic acids}

The main organic acids present in peaches are quinic, malic, citric and succinic. They were quantified by a method adapted from Scherer, Rybka and Godoy (2008). To extract organic acids, two grams of each crushed sample were homogenized with $18 \mathrm{~mL}$ of aqueous solution of $\mathrm{KH}_{2} \mathrm{PO}_{4} 0.01 \mathrm{M}$, at $\mathrm{pH}$ adjusted to 2.6 with phosphoric acid. The samples were then vacuum filtered through Whatman 1 paper and subsequently filtered through a $0.46 \mu \mathrm{m}$ membrane before injection.

Organic acid measurements were performed using a HP (Agilent) 1100 series high-performance liquid chromatograph (HPLC) equipped with degasser and HP quaternary pump system, automatic injector, spectrophotometric detector with diode array simultaneously adjusted to 212 and $220 \mathrm{~nm}$, and Chemstation software to obtain and process data. A C-18 reversephased column, Synergy $4 \mu$ Hydro-RP $80 A(250 \times 4.6 \mathrm{~mm}$ ID $)$ was used at $24^{\circ} \mathrm{C}$ for chromatographic separation. The mobile phase was a $0.02 \mathrm{M} \mathrm{KH}_{2} \mathrm{PO}_{4}$ aqueous solution with the $\mathrm{pH}$ adjusted to 2.9 isocratically at a $0.7 \mathrm{~mL} \mathrm{~min}^{-1}$ flow of phosphoric acid. Organic acids were quantified using 5-point analytical curves, with the largest concentration of $0.5 \mathrm{mg} \mathrm{mL}^{-1}$, Sigma standards from Supelco and identification by retention times and by comparison with the standard absorption spectra.

\subsection{Statistical analysis}

The descriptive statistical analysis was performed, with results expressed by mean values and respective standard deviations. Means were compared by the Scott-Knott test at a 5\% significance level using the software Sisvar (FERREIRA, 2003). 


\section{Results and discussion}

\subsection{Determination of total sugars}

Sucrose is the most abundant sugar in peaches, followed by reducing sugars glucose and fructose (CHITARRA; CHITARRA, 2005). According to Esti, Desphande and Salunke (1997), sucrose levels in peaches may vary from 4.3

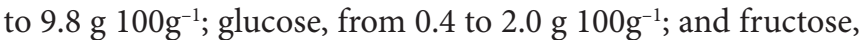

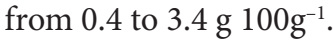

Most of the analyzed varieties presented levels of reducing, non-reducing and, consequently, total sugars significantly higher in non-bagged fruit. Total sugar ranged from 4.26 to

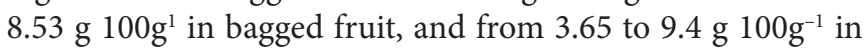
non-bagged fruit. These results show that even when bagged, the fruit analyzed in this work presented total and reducing sugar levels similar to those found in peaches produced in other areas of Brazil, and that there were significant variations among cultivars. Since high sugar content usually indicates good fruit quality, the fruit analyzed herein are indicated for fresh consumption as well as for industrial processing. The cultivar with the highest total sugar concentration was "Maciel”, followed by "Diamante" and "T. Beauty". The lowest total sugar levels were found in cultivars "C.1122" and "C.843", as shown in Table 1. Only for three of the 16 analyzed varieties, total sugar content was not significantly different between bagged and non-bagged fruit: “C.845", "Ouromel 2" and "Sensação".

The difference in sugar concentrations is due to the genotypic characteristics of the varieties, to cultivation factors, to the greater sun exposure of non-bagged fruit and to the maturation time, with some varieties ripening and being harvested in warmer periods (November and December), as is the case of cultivar "Maciel". Toralles et al. (2008) analyzed cultivar "Maciel" and observed a lower sugar level (8.2 g 100g-1) than the observed in this work, but registered later harvest and sweeter varieties such as "Eldorado", "Magno" and "BR-6" with non-bagged fruit produced in the area of Pelotas, Rio Grande do Sul State, Brazil.

Analyzing different types of paper for peach bagging, Telles et al. (2004) found that when using parchment paper, which was the clearest and most transparent of those tested, the fruit presented higher percentages of red and higher content of soluble solids, since sunlight influences skin pigmentation making it more intense and giving higher quality aspect to the peaches. Studies using clear plastic bags are not found in the literature, so we were unable to verify whether the benefits of fruit bagging could extend to the chemical components, given the greater sun exposure.

Firmer and less sweet varieties are generally better utilized in the food industry, as is the case with "BRS Libra" (RASEIRA, 2010).

\subsection{Total phenols and carotenoids}

Table 2 lists the results of total phenols and total carotenoids. The first ranged from 21.10 to $70.37 \mathrm{mg}$ of tannic acid per $100 \mathrm{~g}$ of bagged fruit, and from 24.90 to $79.38 \mathrm{mg}$ of tannic acid per $100 \mathrm{~g}$ of non-bagged fruit, with significantly higher levels in non-bagged fruit.

The largest difference between bagged and non-bagged fruit was observed for variety "Diamante" (34.12 mg $100 \mathrm{~g}^{-1}$ in

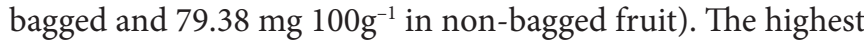
total phenol levels were found in non-bagged fruit of yellower varieties such as "Diamante", "C.693" and "C.843", with most cultivars presenting concentrations lower than $50 \mathrm{mg} 100 \mathrm{~g}^{-1}$, especially in bagged fruit.

Table 1. Total sugars, reducing and non-reducing, in 16 varieties of peaches harvested in 2010 in Maria da Fé/MG.

\begin{tabular}{|c|c|c|c|c|c|c|}
\hline \multirow{2}{*}{ Samples } & \multicolumn{2}{|c|}{ Total Sugars $\left(\mathrm{g} 100 \mathrm{~g}^{-1}\right)$} & \multicolumn{2}{|c|}{ Reducing Sugars $\left({\left.\mathrm{g} 100 \mathrm{~g}^{-1}\right)}\right.$} & \multicolumn{2}{|c|}{ Non-Reducing Sugars $\left(\mathrm{g} 100 \mathrm{~g}^{-1}\right)$} \\
\hline & Bagged & Non-Bagged & Bagged & Non-Bagged & Bagged & Non-Bagged \\
\hline Azetec Gold & $5.65 \pm 0.13 \mathbf{B d}$ & $4.43 \pm 0.12 \mathrm{Ab}$ & $1.31 \pm 0.09 \mathrm{Ac}$ & $1.30 \pm 0.14 \mathrm{Ac}$ & $4.12 \pm 0.20 \mathrm{Bc}$ & $2.97 \pm 0.02 \mathbf{A b}$ \\
\hline Cascata 663 & $4.81 \pm 0.00 \mathbf{A b}$ & $6.56 \pm 0.24 \mathbf{B d}$ & $0.97 \pm 0.04 \mathbf{A a}$ & $1.09 \pm 0.12 \mathbf{B b}$ & $3.65 \pm 0.04 \mathbf{A b}$ & $5.19 \pm 0.34 \mathbf{B d}$ \\
\hline Cascata 1015 & $5.89 \pm 0.01 \mathrm{Ad}$ & $7.24 \pm 0.01 \mathrm{Be}$ & $1.23 \pm 0.09 \mathrm{Ac}$ & $1.52 \pm 0.013 \mathbf{B d}$ & $4.42 \pm 0.09 \mathrm{Ac}$ & $5.43 \pm 0.00 \mathrm{Bc}$ \\
\hline Cascata 1056 & $5.72 \pm 0.16$ Ad & $7.85 \pm 0.03 \mathbf{B f}$ & $1.40 \pm 0.09 \mathrm{Ad}$ & $1.81 \pm 0.01 \mathrm{Be}$ & $4.11 \pm 0.25 \mathrm{Ac}$ & $5.74 \pm 0.01 \mathbf{B f}$ \\
\hline Conserva 693 & $5.37 \pm 0.07 \mathrm{Ac}$ & $6.49 \pm 0.13 \mathbf{B d}$ & $1.44 \pm 0.04 \mathrm{Ad}$ & $1.53 \pm 0.02 \mathrm{Ad}$ & $3.73 \pm 0.10 \mathbf{A b}$ & $4.71 \pm 0.14 \mathbf{B c}$ \\
\hline Conserva 843 & $4.26 \pm 0.03 \mathrm{Aa}$ & $6.62 \pm 0.01 \mathbf{B d}$ & $0.90 \pm 0.00 \mathrm{Aa}$ & $1.65 \pm 0.00 \mathrm{Be}$ & $3.19 \pm 0.03 \mathrm{Aa}$ & $4.72 \pm 0.01 \mathrm{Bc}$ \\
\hline Conserva 845 & $7.54 \pm 0.07$ Af & $7.73 \pm 0.06$ Af & $1.55 \pm 0.06 \mathbf{B e}$ & $1036 \pm 0.02 \mathrm{Ac}$ & $5.70 \pm 0.13 \mathrm{Ae}$ & $6.02 \pm 0.04$ Af \\
\hline Conserva 1050 & $7.07 \pm 0.16 \mathbf{B f}$ & $5.88 \pm 0.01 \mathrm{Ac}$ & $1.10 \pm 0.18 \mathbf{B b}$ & $0.94 \pm 0.06 \mathbf{A a}$ & $5.67 \pm 0.02 \mathbf{B e}$ & $4.69 \pm 0.05 \mathrm{Ac}$ \\
\hline Conserva 1122 & $5.30 \pm 0.27 \mathbf{B c}$ & $3.65 \pm 0.07 \mathrm{Aa}$ & $0.84 \pm 0.04 \mathbf{A a}$ & $0.98 \pm 0.05 \mathbf{B a}$ & $4.23 \pm 0.22 \mathrm{Bc}$ & $2.54 \pm 0.02 \mathrm{Aa}$ \\
\hline BRS Libra & $5.32 \pm 0.19 \mathrm{Ac}$ & $6.47 \pm 0.03 \mathbf{B d}$ & $1.72 \pm 0.00 \mathbf{~ A f}$ & $1.78 \pm 0.05 \mathbf{A e}$ & $3.43 \pm 0.18 \mathrm{Aa}$ & $4.45 \pm 0.02 \mathbf{B c}$ \\
\hline Diamante & $8.28 \pm 0.02 \mathrm{Ag}$ & $8.80 \pm 0.57 \mathrm{Bg}$ & $2.25 \pm 0.04 \mathrm{Bg}$ & $1.75 \pm 0.01 \mathrm{Ae}$ & $5.73 \pm 0.02 \mathrm{Ae}$ & $6.70 \pm 0.54 \mathbf{B g}$ \\
\hline Fla 8813 & $7.23 \pm 0.04 \mathbf{B f}$ & $6.04 \pm 0.03 \mathrm{Ac}$ & $1.55 \pm 0.01 \mathrm{Ae}$ & $1.48 \pm 0.00 \mathrm{Ad}$ & $5.39 \pm 0.03 \mathbf{B d}$ & $4.34 \pm 0.03 \mathrm{Ac}$ \\
\hline Ouromel 2 & $6.40 \pm 0.03 \mathrm{Ae}$ & $6.22 \pm 0.06 \mathrm{Ac}$ & $0.99 \pm 0.02 \mathbf{B a}$ & $0.84 \pm 0.03 \mathbf{A a}$ & $5.14 \pm 0.02 \mathrm{Ad}$ & $5.11 \pm 0.03$ Ad \\
\hline Sensação & $6.72 \pm 0.08 \mathrm{Ae}$ & $6.77 \pm 0.70$ Ad & $1.40 \pm 0.04$ Ad & $1.38 \pm 0.05 \mathrm{Ac}$ & $5.05 \pm 0.04$ Ad & $5.12 \pm 0.71$ Ad \\
\hline Tropic Beauty & $6.69 \pm 0.07 \mathrm{Ae}$ & $8.64 \pm 0.29 \mathbf{B g}$ & $1.61 \pm 0.05 \mathrm{Ae}$ & $1.80 \pm 0.07 \mathbf{B e}$ & $4.83 \pm 0.11$ Ad & $6.50 \pm 0.34 \mathbf{B g}$ \\
\hline Maciel & $8.53 \pm 0.03 \mathbf{A g}$ & $9.40 \pm 0.06 \mathbf{B h}$ & $1.67 \pm 0.01 \mathbf{~ A f}$ & $1.55 \pm 0.01 \mathrm{Ad}$ & $6.52 \pm 0.03$ Af & $7.46 \pm 0.05 \mathbf{B h}$ \\
\hline CV (\%) & \multicolumn{2}{|c|}{2.96} & \multicolumn{2}{|c|}{4.45} & \multicolumn{2}{|c|}{4.12} \\
\hline
\end{tabular}

Means and standard deviations. Upper case letters compare varieties between conditions (bagged and non-bagged). Lower case letters compare varieties under the same condition. Means followed by the same letter are not significantly different by the Scott-Knott test at $5 \%$ level. 
Lima et al.

Table 2. Total phenols and total carotenoids in 16 varieties of peaches harvested in 2010 in Maria da Fé/MG.

\begin{tabular}{|c|c|c|c|c|}
\hline \multirow{2}{*}{ Samples } & \multicolumn{2}{|c|}{ Total Phenols (mg 100g $\left.\mathrm{g}^{-1}\right)$} & \multicolumn{2}{|c|}{ Total Carotenoids $\left(\mathrm{mg}^{\left.100 \mathrm{~g}^{-1}\right)}\right.$} \\
\hline & Bagged & Non-Bagged & Bagged & Non-Bagged \\
\hline Azetec Gold & $21.10 \pm 0.77 \mathbf{A a}$ & $34.12 \pm 0.77 \mathbf{B b}$ & $0.98 \pm 0.04 \mathbf{A a}$ & $0.89 \pm 0.11 \mathbf{A a}$ \\
\hline Cascata 663 & $45.74 \pm 0.61 \mathbf{B i}$ & $32.93 \pm 0.31 \mathbf{A b}$ & $0.83 \pm 0.08 \mathbf{A ~ a}$ & $0.79 \pm 0.12 \mathbf{A a}$ \\
\hline Cascata 1056 & $39.22 \pm 0.61 \mathbf{A g}$ & $57.13 \pm 2.3 \mathbf{B f}$ & $1.11 \pm 0.28 \mathrm{~A} \mathrm{a}$ & $1.02 \pm 0.12 \mathrm{Aa}$ \\
\hline Conserva 693 & $70.37 \pm 2.92 \mathbf{B k}$ & $67.44 \pm 0.61 \mathbf{A i}$ & $1.21 \pm 0.08 \mathbf{A ~ a}$ & $0.96 \pm 0.13 \mathbf{A a}$ \\
\hline Conserva 1050 & $31.08 \pm 0.15 \mathbf{B d}$ & $27.07 \pm 0.00 \mathrm{Aa}$ & $1.41 \pm 0.11 \mathrm{~A} \mathrm{a}$ & $1.87 \pm 0.18 \mathrm{Bc}$ \\
\hline Conserva 1122 & $35.86 \pm 0.15$ Af & $47.26 \pm 0.61 \mathbf{B d}$ & $0.90 \pm 0.01 \mathrm{~A} \mathrm{a}$ & $0.86 \pm 0.05 \mathrm{Aa}$ \\
\hline BRS Libra & $24.46 \pm 0.61 \mathbf{A b}$ & $24.90 \pm 0.00 \mathrm{Aa}$ & $1.32 \pm 0.00 \mathrm{~A} \mathrm{a}$ & $1.39 \pm 0.23 \mathbf{A b}$ \\
\hline Diamante & $34.12 \pm 0.46 \mathbf{A e}$ & $79.38 \pm 1.23 \mathbf{B j}$ & $1.83 \pm 0.01 \mathbf{A ~ b}$ & $1.97 \pm 0.03 \mathrm{Ac}$ \\
\hline Fla 8813 & $45.19 \pm 0.77 \mathbf{A i}$ & $47.80 \pm 0.77 \mathbf{B d}$ & $0.95 \pm 0.22 \mathrm{~A} \mathrm{a}$ & $1.29 \pm 0.17 \mathbf{A b}$ \\
\hline CV (\%) & \multicolumn{2}{|c|}{2.41} & \multicolumn{2}{|c|}{14.77} \\
\hline
\end{tabular}

Means and standard deviations. Upper case letters compare varieties between conditions (bagged and non-bagged). Lower case letters compare varieties under the same condition. Means followed by the same letter are not significantly different by the Scott-Knott test at $5 \%$ level.

Analyzing different peach varieties, Gil et al. (2002) found levels ranging from 22.80 to $168.00 \mathrm{mg}$ of gallic acid $100 \mathrm{~g}^{-1}$ of pulp, and larger levels of total phenols and carotenoids in skin than in pulp. In that study, total phenol levels were higher in cultivars with white or less yellow fruit.

The variation in total phenol levels is mainly due to the genotypic differences among cultivars, adaptability to climate and cultivation practices. The values found are compatible with those mentioned in the literature, which reports levels between 12.7 and $71.3 \mathrm{mg}$ of gallic acid equivalent per $100 \mathrm{~g}$ of fruit (CANTÍN; MORENO; GOGORCENA, 2009). However, published studies were not found for many of the varieties considered in this research.

High levels of these secondary compounds are beneficial because they are natural antioxidants, thus they may reduce or prevent damage caused by free radicals in human cells. Besides their relevance in fruit aspect, flavor and scent, phenolic compounds also extend shelf life and inhibit the growth of pathogenic microorganisms due to their natural antimicrobial properties (CANTÍN; MORENO; GOGORCENA, 2009). On the other hand, low total phenol levels are desirable in pulp preparation as puree and juice, since they are involved in enzymatic browning, provide less pulp astringency and nonenzymatic browning, which occurs in some peach cultivars when thermally processed (TORALLES et al., 2008). Therefore, varieties richer in phenols are better for fresh consumption or must undergo a preprocessing chemical treatment in the event of this browning.

Carotenoid content increases with fruit maturation and storage, with part of the color intensification being due to loss of chlorophyll (SEGANTINI et al., 2012). According to Sentanin and Rodriguez-Amaya (2007), the main carotenoids present in peaches are $\beta$-cryptoxanthin, $\beta$-carotene and violaxanthin. Total

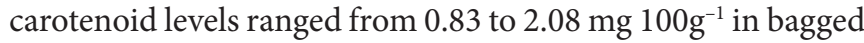

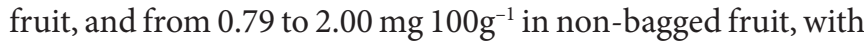
only three varieties showing significant differences regarding bagging, as seen in Table 2. This evidences that bagging did not contribute to changes in fruit color pattern. The varieties richest in carotenoids were "Maciel", "Diamante", "C.845”, "C.843", “C.1050" and "Sensação".

In the literature, carotenoid levels vary greatly among cultivars. Segantini et al. (2012) found levels ranging from 35.94 to $81.58 \mu \mathrm{g} 100 \mathrm{~g}^{-1}$ in yellow pulp cultivars produced in Brazil, quantified by colorimetric methods. Gil et al. (2002) observed values between 0.362 and $0.512 \mathrm{mg} 100 \mathrm{~g}^{-1}$ in yellow peaches from California, United States, using liquid chromatography. Manica-Berto (2008), who colorimetrically analyzed cultivar "Jubileu" produced in Rio Grande do Sul, found $3.11 \mathrm{mg} 100 \mathrm{~g}^{-1}$ in the skin and $1.94 \mathrm{mg} 100 \mathrm{~g}-1$ in the pulp. This difference is due to several factors such as genetic variation, maturity stage, postharvest storage, fruit processing and preparation (CAPECKA; MARECZEK; LEJA, 2005).

\subsection{Organic acids}

Malic, quinic and citric acids are the most abundant acids in peaches, with citric acid being the most sensitive to fruit bagging: nearly all varieties presented significant differences between the treatments. Table 3 shows that the levels of such acids are different in each peach variety. Organic acid levels vary significantly during fruit development and, along with other secondary compounds, are responsible for flavor and aroma.

Studies show that quinic acid is the main acid in immature peaches, and that its level decreases rapidly with maturation. Citric acid levels decrease continuously along with quinic acid 
Peach chemical evaluation and bagging effect

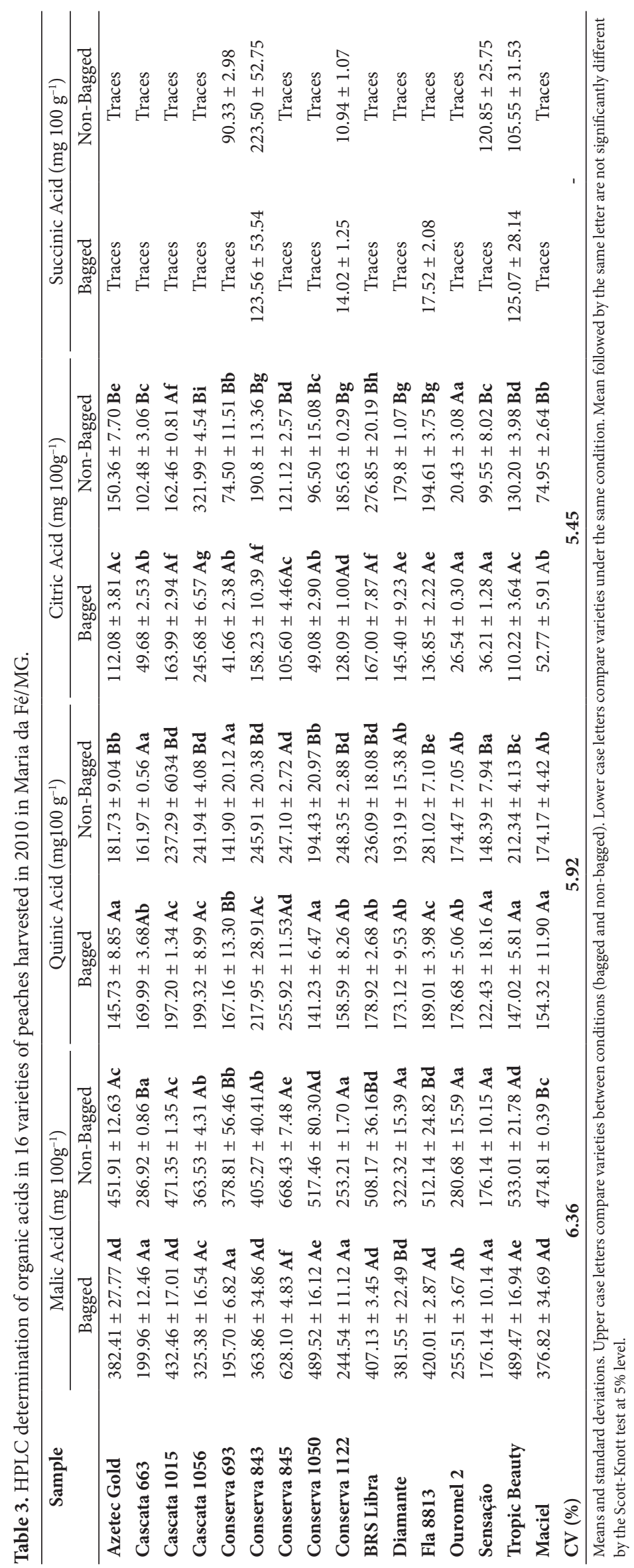


during fruit maturation, when sucrose contents reach maximum levels. After floating around $0.2-0.3 \%$ fresh weight, the malic acid content reaches maximum value, becoming the main acid ( $0.5 \%$ fresh weight) during the final growth stage, and starts decreasing, maintaining approximately $0.4 \%$ fresh weight, thus being the most abundant acid in mature fruit (CHAPMAN; HORVAT, 1990). Wang et al. (1993) observed in varieties Babygold 5, Babygold 7 and Cresthaven (USA) malic acid levels

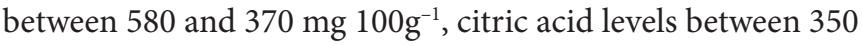

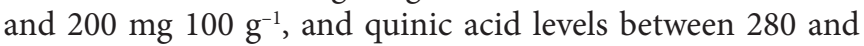
$180 \mathrm{mg} 100 \mathrm{~g}^{-1}$. The contents found in this work are similar to those reported in the literature, which does not include studies with Brazilian peaches. Varieties "C.845", "T. Beauty", "C.1050", "Fla 8813" and "BRS Libra" presented the highest levels of malic acid. Succinic acid was observed in considerable levels only in varieties "C.843" and "T. Beauty", but not detected in most varieties, especially with fruit bagging. The wide range of organic acid contents among varieties may be explained by several factors besides genotype, such as edaphoclimatic and cultivation factors.

A sensory evaluation carried out by Oliveira et al. (2011) with non-bagged fruit from nine of the 16 varieties studied in this work verified that varieties "C.1050", "Ouromel 2" and "Diamante" were the best ones evaluated for aroma, flavor, color and overall appearance. We observed that such varieties presented high sugar and organic acid contents, as well as high total phenol and carotenoid levels.

\subsection{Final considerations}

Bagging is a good way to protect fruits, especially in organic production. Nevertheless, for most peach varieties constituents such as sugars, phenols and organic acids proved to be sensitive to bagging due to reduced sun exposure. We cannot state if the procedure affects the fruit organoleptic characteristics.

Based on the performed analyses, the varieties most appropriate for fresh consumption are "Maciel", "Diamante", "T. Beauty”, “C.1056", “Ouromel 2", “C.1056", “C.845”, "C.843”, "C.693", "Fla 8813" and "C.1015”. Those indicated for industrial processing are "A. Gold”, "C.1122", "C.1050", "Sensação" and "C.663". Many of the analyzed cultivars serve both purposes.

Other factors such as productivity must be observed in order to determine which varieties should be released to producers. These chemical constituent analyses are important to determine varieties that are recommended for the food industry and those for fresh consumption.

\section{Conclusions}

Sugar, phenol, carotenoid and organic acid contents are genotypic characteristics that differ among varieties. The varieties that stood out in this work were "Diamante" and "C.845", both presenting high levels of sugars, organic acids and carotenoids. Variety "Maciel" stood out for sugar and carotenoid levels; "T. Beauty", for sugars and organic acids; "C.1056", for sugars and phenols; "C.843", for phenols and carotenoids; and cultivar "C.1050" for carotenoids and organic acids.
Despite being a good way of protecting fruit, bagging caused a reduction in the levels of constituents such as sugars, phenols and organic acids. We cannot state that it interfered with fruit organoleptic characteristics.

\section{Acknowledgements}

This study was financially supported by FAPEMIG.

\section{References}

ASSOCIATION OF OFFICIAL ANALYTICAL CHEMISTS - AOAC. Official methods of analysis. 15. ed. Washington: AOAC; 1990.

CANTÍN, C. M.; MORENO, M. A.; GOGORCENA, Y. Evaluation of the Antioxidant Capacity, Phenolic Compounds,and Vitamin C Content of Different Peach and Nectarine [Prunus persica (L.) Batsch] Breeding Progenies. Journal of Agriculture and Food Chemistry, v. 57, p. 4586-4592, 2009. http://dx.doi.org/10.1021/ jf900385a

CAPECKA, E.; MARECZEK, A.; LEJA, M. Antioxidant activity of fresh and dry herbs of some Lamiaceae species. Food Chemistry, v. 93, p. 223-226, 2005. http://dx.doi.org/10.1016/j.foodchem.2004.09.020

CHAPMAN, G. W.; HORVAT, R. J. Changes in nonvolatile acids, sugars, pectin and sugar composition of pectin during peach (cv. Monroe) maturation. Journal of Agriculture and Food Chemistry, v. 38, p. 383-387, 1990. http://dx.doi.org/10.1021/jf00092a008

CHITARRA, I. M. F; CHITARRA, A. B. Pós-colheita de frutas e hortaliças: Fisiologia e Manuseio. 2. ed. Lavras: UFLA; 2005.

COELHO, L. R. et al. Control peach crop pests by fruits bagging. Ciência e Agrotecnologia, v. 32, n. 6, p. 1743-1747, 2008. http:// dx.doi.org/10.1590/S1413-70542008000600010

COLARIC, M. S. F.; HUDINA, M. Contents of sugars and organic acids in the cultivars of peach (Prunus persica L.) and nectarine (Prunus persica var. nucipersica Schneid.). Acta agriculturae slovenica, v. 83, n. 1, p. 53-61, 2004.

EMBRAPA. Clima Temperado. Cultivo do Pessegueiro. Sistemas de Produção, n. 4, nov. 2005. Disponível em: <http:// sistemasdeproducao.cnptia.embrapa.br/FontesHTML/Pessego/ CultivodoPessegueiro/cap01.htm>. Acesso em: 18 abr. 2013.

ESTI, M.; DESPHANDE, P. B.; SALUNKE, D. K. Effect of maturity and storage on certain biochemical changes in apricot and peaches. Food Chemistry, v. 60, p. 659-666, 1997.

FERREIRA, D. F. Sisvar. version 4.6 build 61. Lavras: Dex/UFLA; 2003. Disponível em: <http://www.dex.ufla.br/danielff/dff02.htm>.

GIL, M. I. et al. Antioxidant Capacities, Phenolic Compounds, Carotenoids, and Vitamin C Contents of Nectarine, Peach, and Plum Cultivars from California. Journal of Agriculture and Food Chemistry, v. 50, n. 17, p. 4976-4982, 2002.

HIGBY, W. K. A simplified method for determination of some aspects of the carotenoids distribution in natural and carotene fortified orange juice. Journal of Food Science, v. 27, n. 42, p. 42-49, 1962. http://dx.doi.org/10.1111/j.1365-2621.1962.tb00055.x

INSTITUTO BRASILEIRO DE GEOGRAFIA E ESTATÍSTICA - IBGE Cultutas temporárias e permanentes 2010. Produção Agricula Municipal, Rio de Janeiro, v. 37, p. 1-91, 2010 Disponível em: <http://www.ibge.gov.br/home/estatistica/economia/pam/2010/ PAM2010_Publicacao_completa.pdf>. Acesso em: 18 abr. 2013.

LIMA, A. J. B. et al. Anthocyanins, pigment stability and antioxidant activity in jabuticaba [Myrciaria cauliflora (Mart.) O. Berg]. Revista 
Brasileira de Fruticultura, v. 33, n. 3, p. 877-887, 2011. http:// dx.doi.org/10.1590/S0100-29452011000300023

MANICA-BERTO, R. Influência da interenxertia e dos sistemas de condução nas propriedades funcionais do pêssego. 2008. $50 \mathrm{f}$. Dissertação (Mestrado)-Universidade Federal de Pelotas, Pelotas, 2008.

NELSON, N. A. A photometric adaptation of Somogyi method for determination of glucose. Journal of Biological Chemistry, v. 153, n. 1, p. 375-380, 1944.

OLIVEIRA, S. R. et al. Avaliação sensorial de diferentes cultivares de pêssegos. In: SEMINÁRIO DE INICIAÇÃO CIENTÍFICA E TECNOLÓGICA, 8., 2011, Belo Horizonte. Resumos expandidos... EPAMIG, 2011.

RASEIRA, M. C. B. Pêssego cultivar Brs libra. Revista Brasileira de Fruticultura, v. 32, n. 4, p. 961-1296, 2010.

RIBEIRO, E. P.; SERAVALLI, E. A. G. Química de Alimentos. São Paulo: Ed. Edgard Blucher Ltda., 2004.

SCHERER, R.; RYBKA, A. C. P.; GODOY, H. T. Determinação simultânea dos ácidos orgânicos tartárico, málico, ascórbico e cítrico em polpas de acerola, açaí e caju e avaliação da estabilidade em sucos de caju. Química Nova, v. 31, n. 5, p. 1137-1140, 2008. http://dx.doi.org/10.1590/S0100-40422008000500039

SEGANTINI, D. M. et al. Caracterização da polpa de pêssegos produzidos em São Manuel-SP. Ciência Rural, v. 42, n. 1, p. 52-57, 2012. http:// dx.doi.org/10.1590/S0103-84782012000100009

SENTANin, M. A.; RODRIGUEZ-AMAYA, D. B. Teores de carotenóides em mamão e pêssego determinados por cromatografia líquida de alta eficiência. Ciência e Tecnologia de Alimentos, v. 27 , n. 1, p. 13-19, 2007. http://dx.doi.org/10.1590/S010120612007000100003

TELLES, C. A. et al. Produção e qualidade de pêssegos ensacados da cultivar Coral. Agropecuária Catarinense, v. 17, n. 1, p. 8386, 2004

TORALLES, R. T. et al. Características físicas e químicas de cultivares brasileiras de pêssegos em duas safras. Revista Brasileira de Agrociência, v. 14, n. 2, p. 327-338, 2008.

WANG, T. et al. Organic Acid Changes During Ripening of Processing Peaches. Journal of Food Science, v. 58, n. 3, p. 631-632, 1993. http://dx.doi.org/10.1111/j.1365-2621.1993.tb04343.x 